\title{
قلق الإمتحان لدى طلاب المرحلة الثانوية
}

\author{
إعراد \\ الباحثة/ لطفيه سعيد المبروك البقار \\ إشراف \\ أ.د/حسيز محمد سعد اللديز الحسيني \\ أستاذ علم النفس \\ كليتّالآدابـ جامعتشالمنصورة \\ المجلت العلميت لكليت رياض الأطفال ـ جامعت المنصورة \\ المجلد الثانى_ العدد الرابع

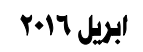




\section{قلق الإمتحان لدى طلاب المرحلة الثانوية}

الباحثت / لطفيه سعيد المبروك البقار”

ويمثل قلق الامتحان أحد المتغيرات التي تحظى باهتمام البــاحثين فـي

مجال دافعية الإنجاز ، بل ويذهب بعض الباحثين في هذا المجال إلى حد القــول

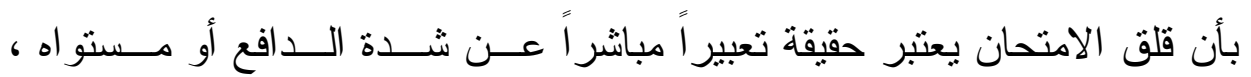

وبالتالي فقد لجأ عدد من الباحثين إلى اعتبار مستوى القلق دلالة علــى دافعيــة

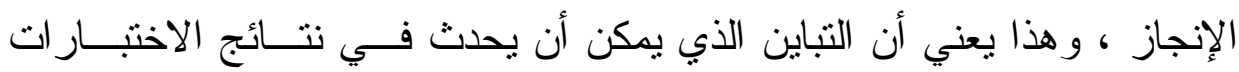

الدر اسية يرجع في حقيقته إلى تباين فيما لدى الأفر اد من دافعية للإنجــاز (علــي

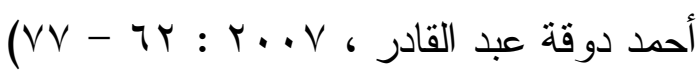

كما يمكن تحديده على أنه،حالة نفسية ترتبط بــالخوف مــن الامتحانــات تظهر في شكل مجموعة من الإثار ات الفسيولوجية و النفسية منل الثعور بـالقلق و التوتز وتشتت الفكر ، وبعض الأعر اض البدنية المؤلمة التي تحــدث قبــلـ أو أثناء الامتحان ، وتهدف بوصفها حالة غير شعورية إلى تجنب الامتحان وتــؤثز سلبا على قدرة الفرد على التفكير السليم واسترجاع المعلومات ونتظيمها خــلد العملية الاختباريةبدرجة تؤدي إلى إضعاف مستوى الأداء في الامتحان ، هــذه الحالة يمكن أن تؤثز سلبا على إنجاز الفرد بصفة عامة ، كما تؤثز على سـلـوكه ونو ازنه الانفعالي ، ومفهومه عن ذاته بصفة خاصة .

"بحث مستخلص من رسالت ماجستير للباحث

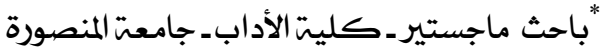


ويرى" كولروهو لان"( • (199) أن قلق الامتحان يمتل أهميــة بالغـــة فــي

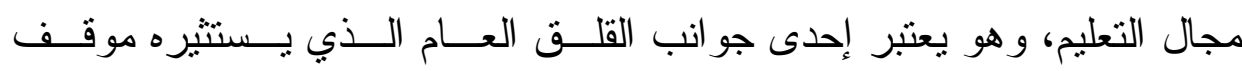

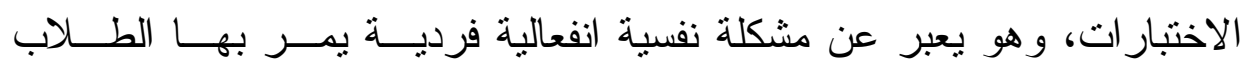

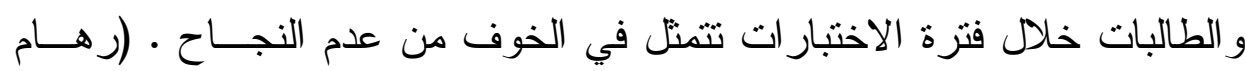

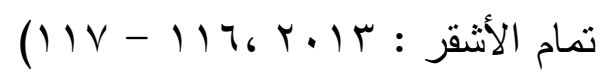

كما يسمى قلق الامتحان أحبانا قلق التحصيل، وهو نوع من القلق المرتبط

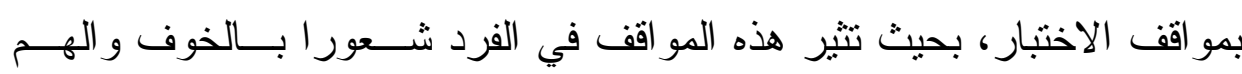

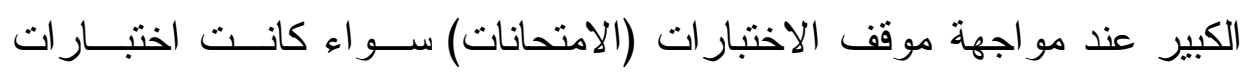

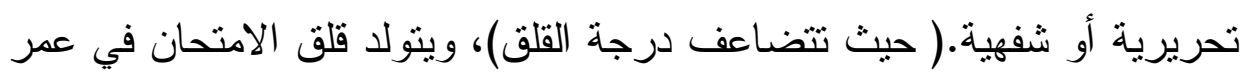

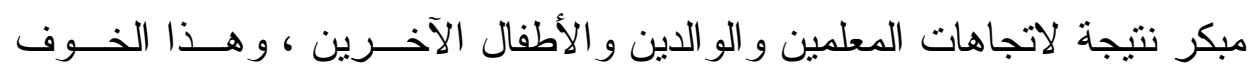

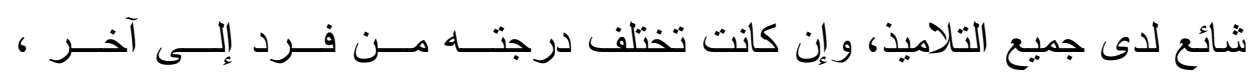

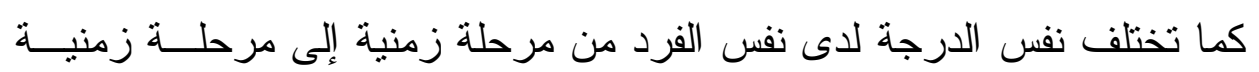

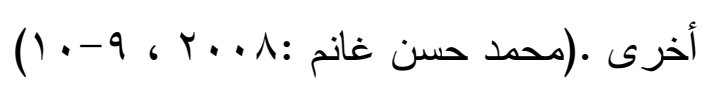

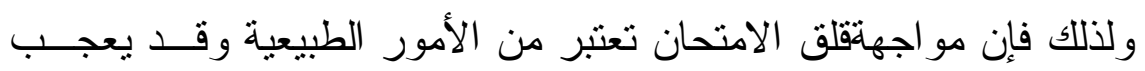

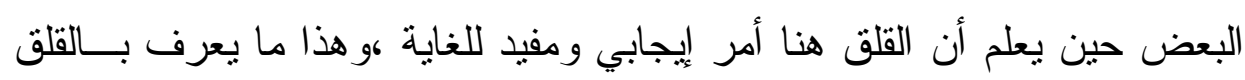

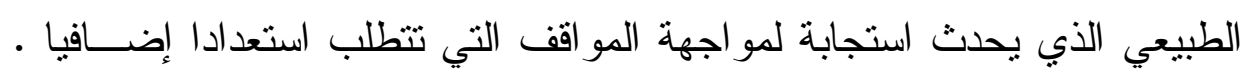

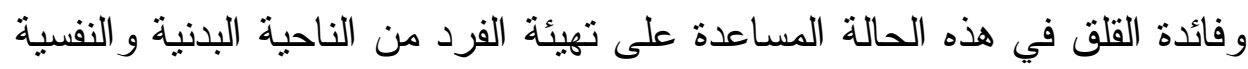

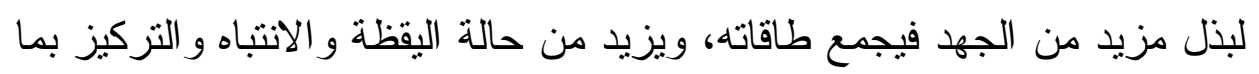

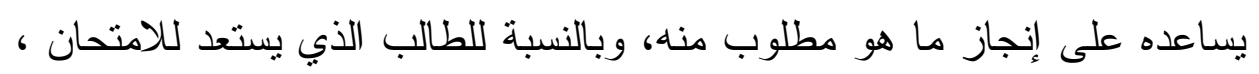

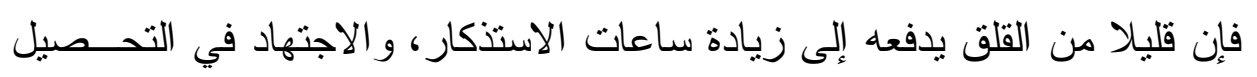

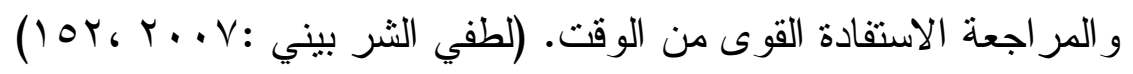


و وأما في المو اقف التعليمية المدرسية فيعد القلق من أهم المشكلات التـي

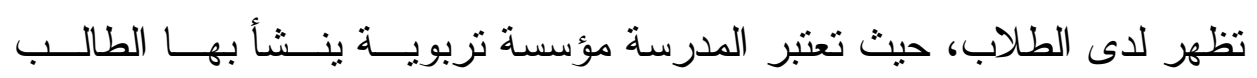

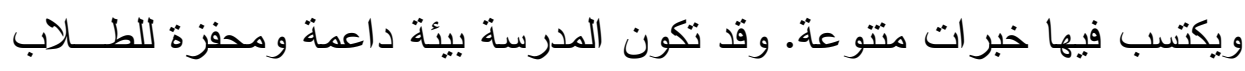
في مو اقف الاختبار، مما ينعكس ايجابيا على تحصيلهم الأكاديمي و على الفاعلية

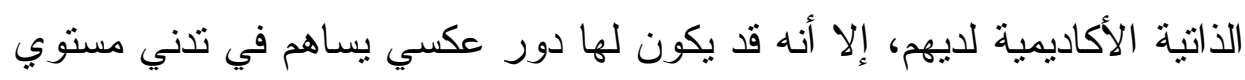

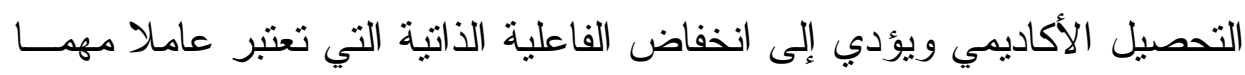

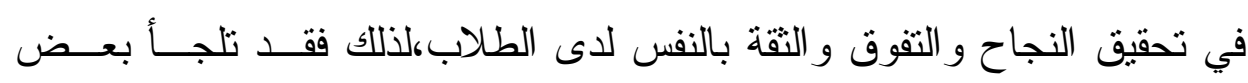

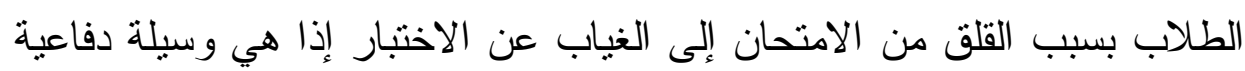

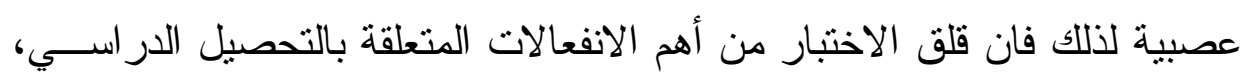

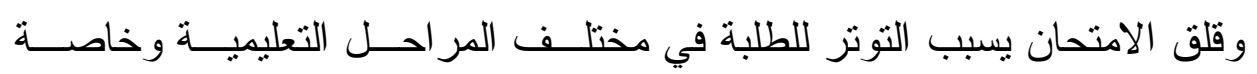
المرحلة الثانوية.

فالتلميذ الذي يعاني من قلق الامتحان يفكر بطريقة غير عقلانيــة وغيــر

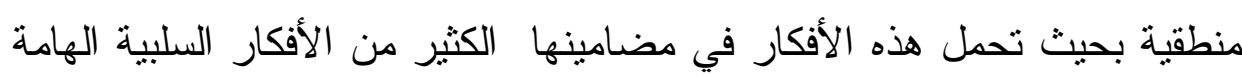

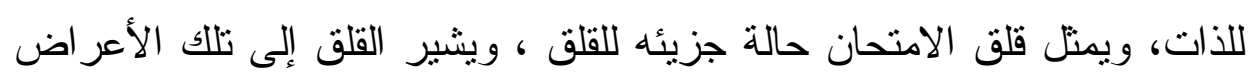

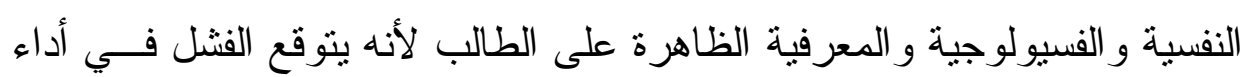

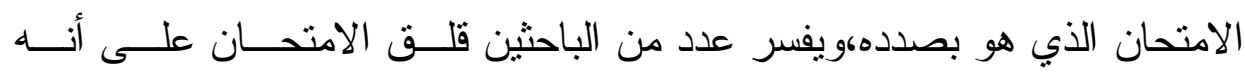

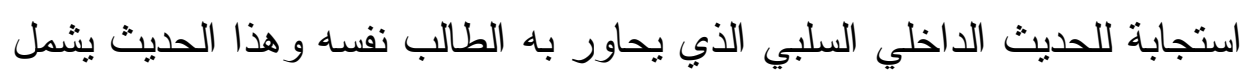

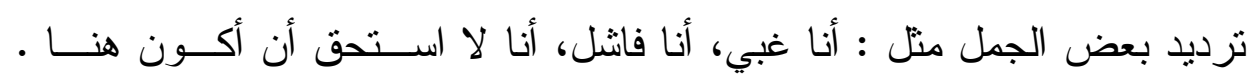

(Dutlce\&Stober. 2001)

إضـافة لذلك فإن فقدان الأثتخاص الذين يعانون من القلق الجــزء الأكبـــر

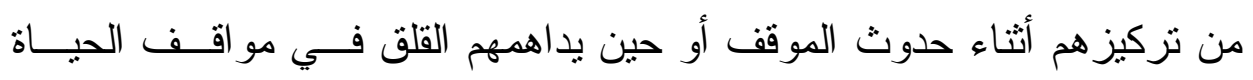


المختلفة كأوقات الاختبار ات.فالطالب يفقد الــسيطرة علـى مجريــات التقكيـر

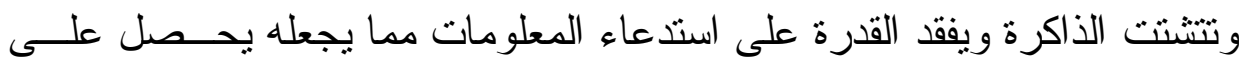

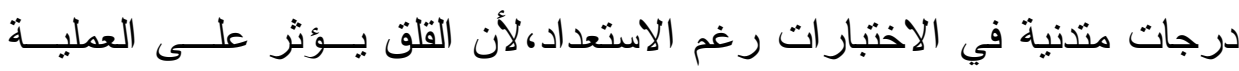

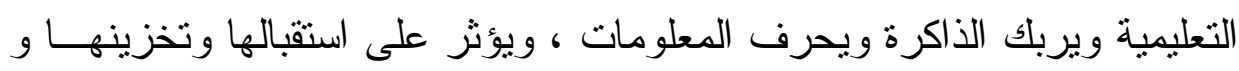

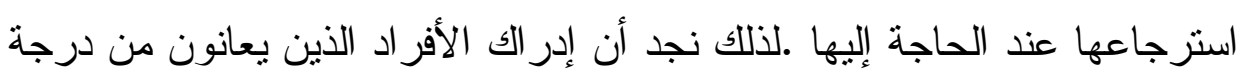

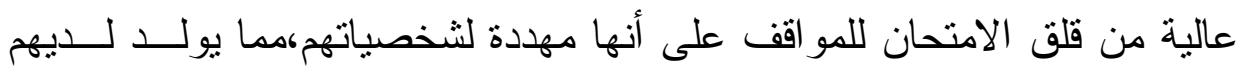

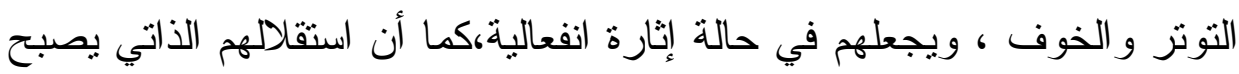
في حالة سلبية جر اء خبر اتهم المؤلمة، ولهذا يتشتت انتباههم وتركبز هم في أنثاء التهاء

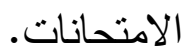

لذلك فإن الإحساس بأهية الامتحان بعد دافعا طبيعيا لمزيد من التحضير

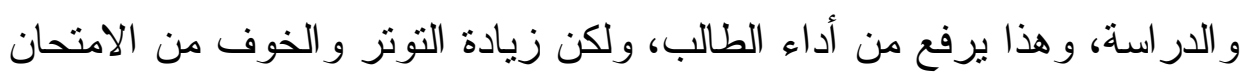

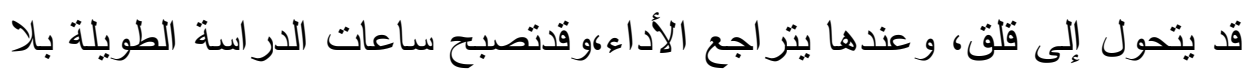

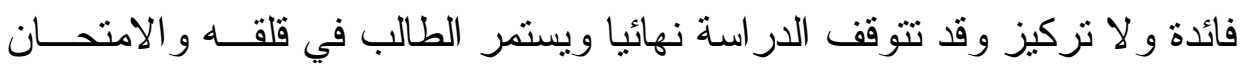
يقترب، و الدر اسة تنز اجع، ولكن الحديث عن الامتحان و الدر اسة و النصائح مسن فئن

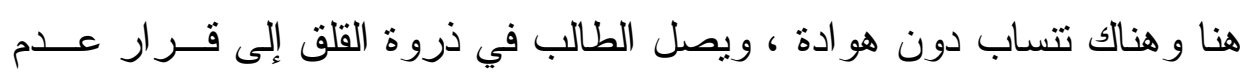

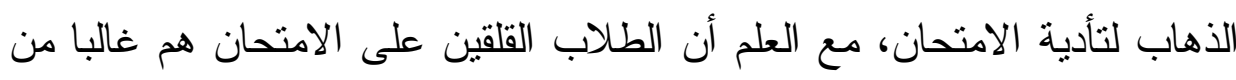

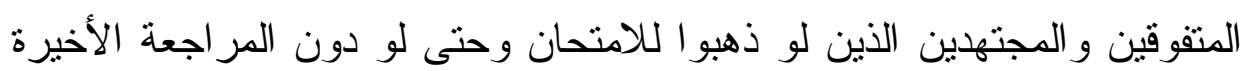

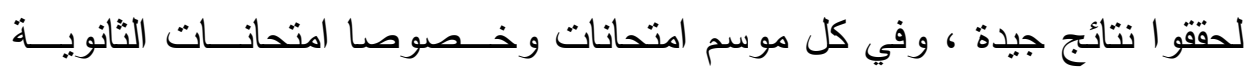

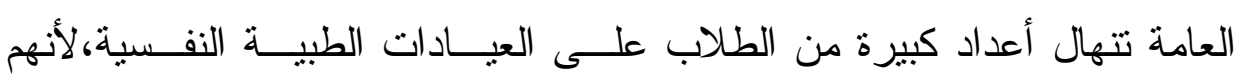

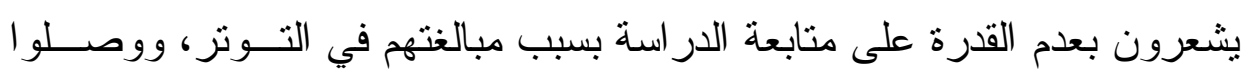

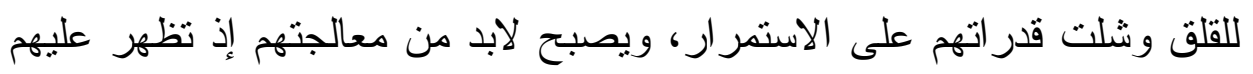

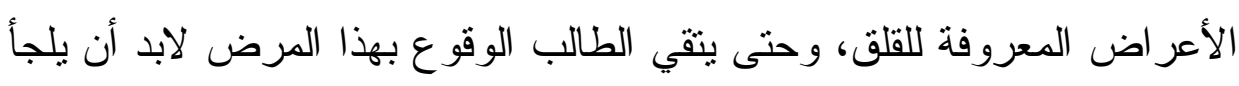


إلى أسلوب دراسي صحيح بغض النظر عن مستو اهو عمرهومرحلــة الدراســـة

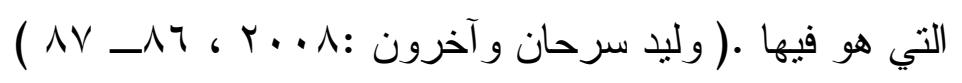

ومما سبق يمكن القول أن قلق الامتحان ظاهرة عامة تصيب كل النـاس

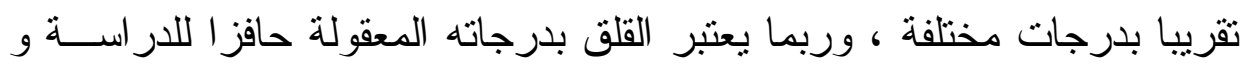

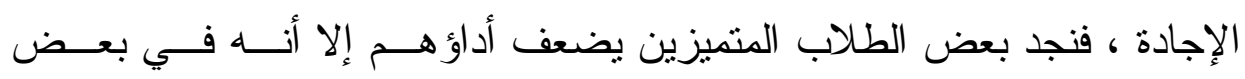

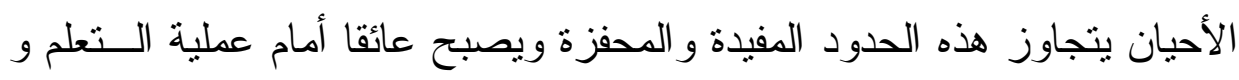

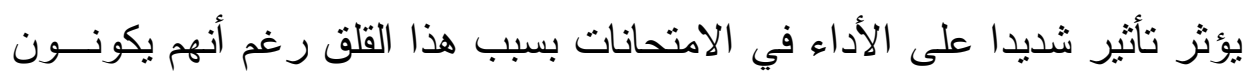

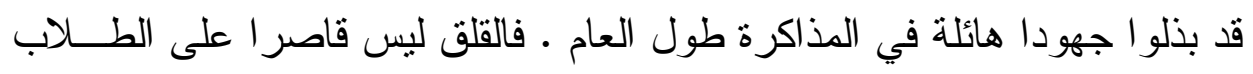

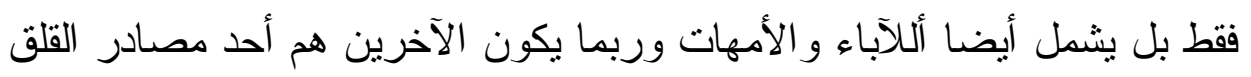

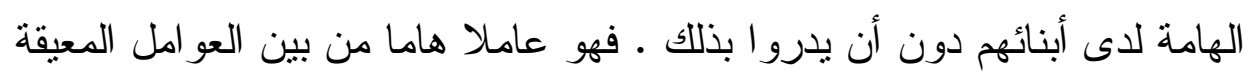

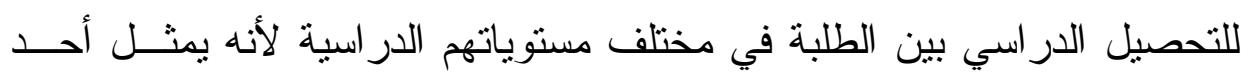

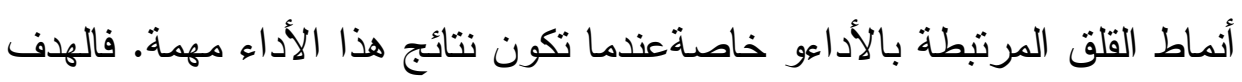

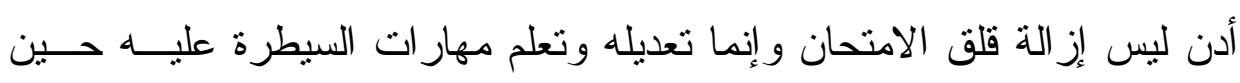

$$
\text { تيتجاوز حدوده الطبيعية. }
$$

تعددت التعريفات التي تتاولت موضوع قلق الامتحان، ولقد عرفه كثيــر

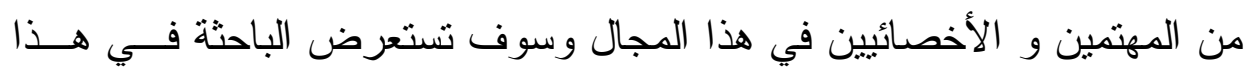

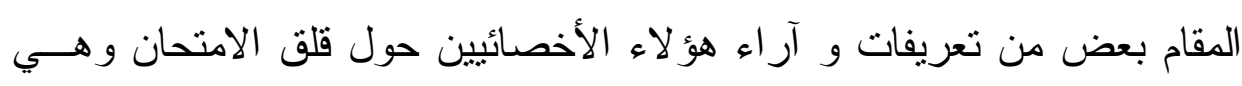
كالتالي:

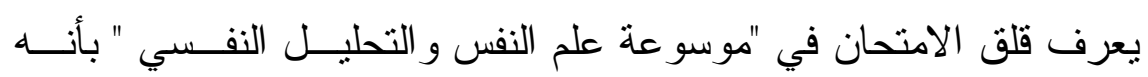

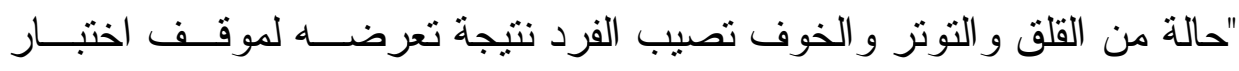


يطبق عليه، سو اء لنقله إلى سنوات در اسية أعلى، أو لمعرفة مــدى صــلاحيته

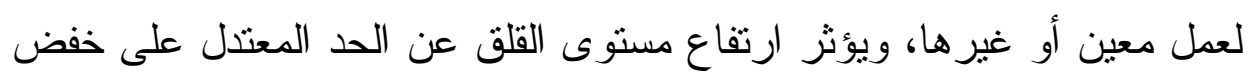

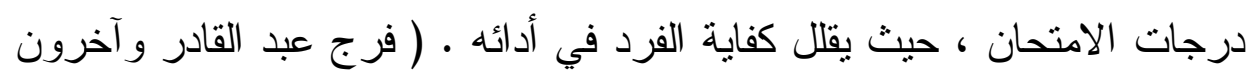
( TVY, r...r:

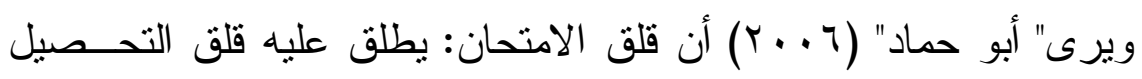

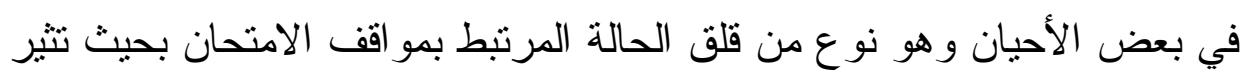

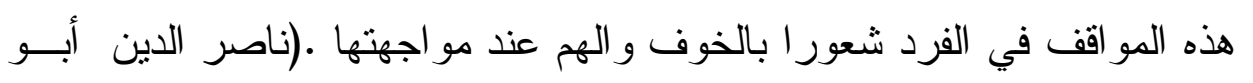

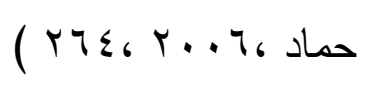

ويعرف "جون، Gohn" (910 1) قلق الامتحان بأنه : حالـــة يمـر بهــا

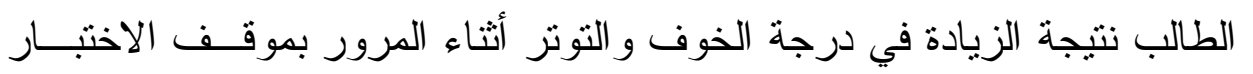
وكذلك الاضطر اب في النواحي الانفعالية و المعرفية و الفسيولوجية. ( عقل محمود ع (r

ويري "أحمد عبد الخالق "(9Av (1) قأن قلق الامتحان: يطلق عليه في بعض

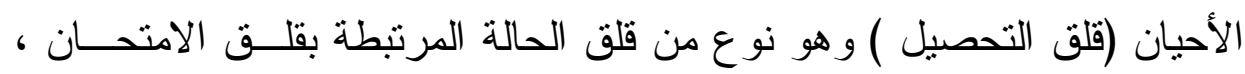

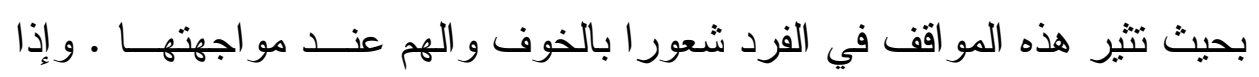

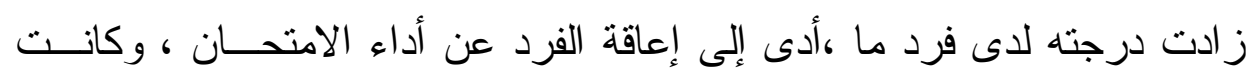

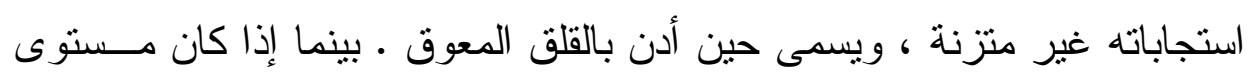

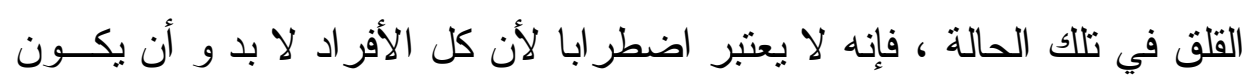

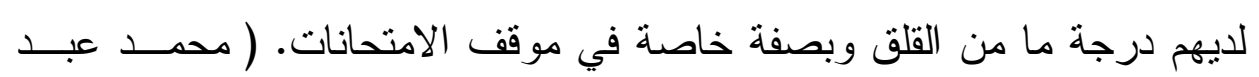

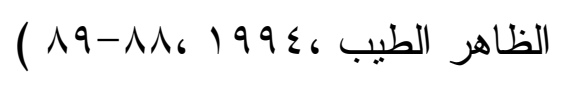


بينما تعرف الباحثة قلث الامتحان بأنه : حالة من الضيق و التوتر التـي

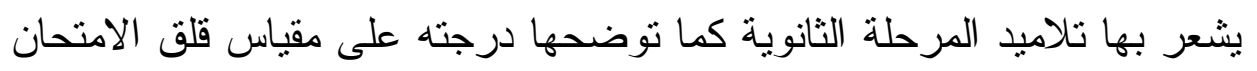

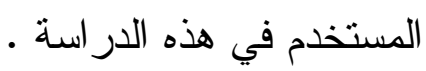

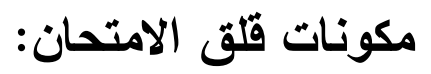

يشير المهتمين في هذا المجال إلى أن قلق الامتحـــان يتـضـمن مكـــين أساسين هما كالتالي :

1- المكون المعرفي: حيت ينشغل الفرد بالتفكير في تبعات الفشل، منل فقدان المكانة و التقدير ، وهذا يمتل سمة القلق.

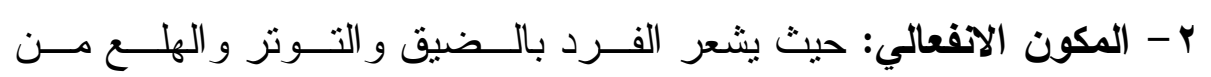

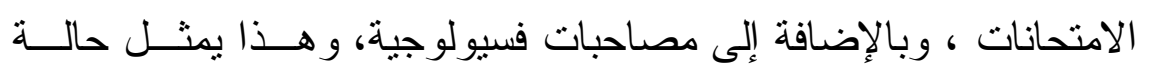

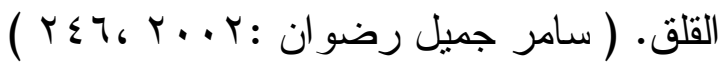

$$
\begin{aligned}
& \text { أسباب قلق الامتحان : }
\end{aligned}
$$

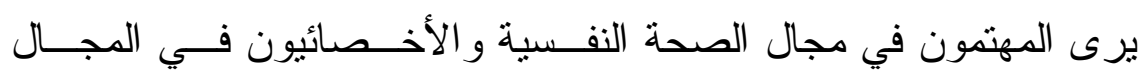
التربوي أن قلق الامتحان يعزى إلى العديد من الأسباب لعل من أبرز ها التالي: - نقص الرغبة في النجاح و التفوق.

- وجود مشكلات في تعلم المعلومات أو تتظيمها أو مر اجعتها قبل الامتحــان، أو استخعائها في موقف الامتحان ذاته. - ارتباط الامتحان بخبرة الفنل في حياة الطالب، وتكر ار مرات الفتل. 
ـ قصور في الاستعداد للامتحان كما يجب، وقــصور فــي مهـار ات اخــذ

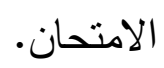
- التمركز حول الذات ، ونقص الثقة بالنفس . - الاتجاهات السالبة لدى الطلاب و المعلمين و الو الدين نحو الامتحان . - صعوبة الامتحانات و الثعور بان المستقبل ينوقف على الامتحانات. - الضغوط البيئية وخاصة الأسرية، لتحقيق مستوى طموح لا يتتاسـب مــع

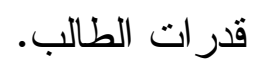
ـ الضغوط المباثرة، حين يتعرض الطالب للتهديد أو يو اجه الفنثل. - محاولة إرضاء الو الدين و المعلمين و المنافسة مع الرفاق. - العجز المتعلم ونوقع الفنظل ونقص السيطرة .

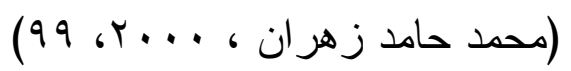

ويمكن القول أن الأسباب ور اء قلق الامتحانات متتوعة منها مـــا يتعلــق

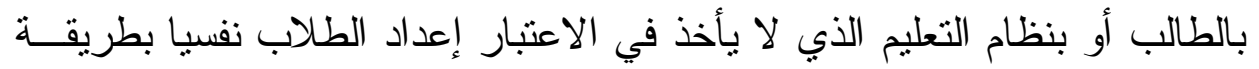

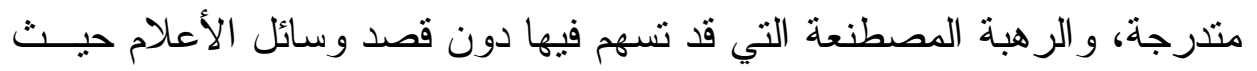

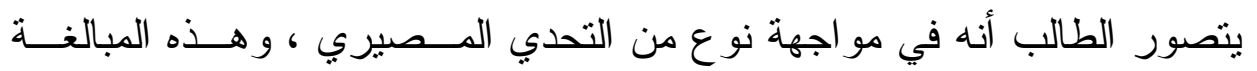
تسبب المزيد من الضغط النفسي و القلق.ونصيحة الطب النفسي في هذه الحالـــة النها

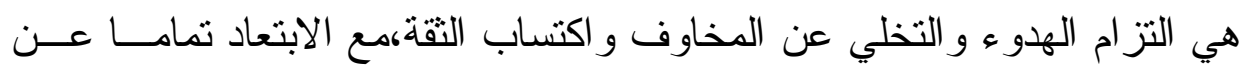

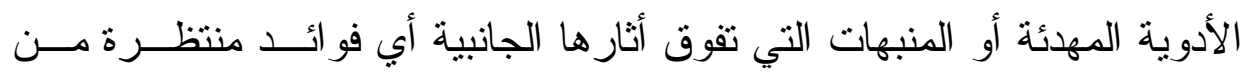

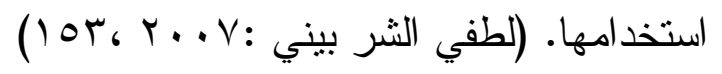


وترى الباحثة أن الثخصية القلقة بطبعها من أكثر الثخصيات عرضـــة

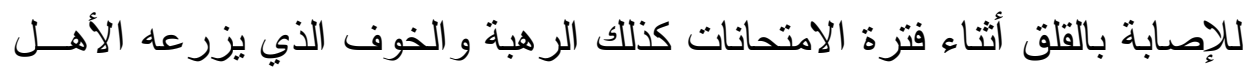

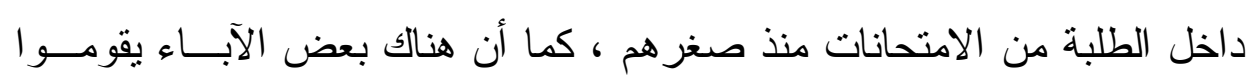

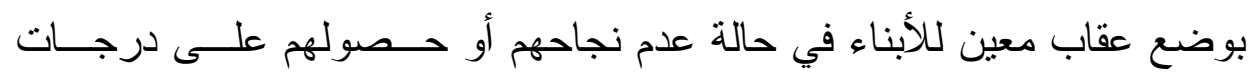

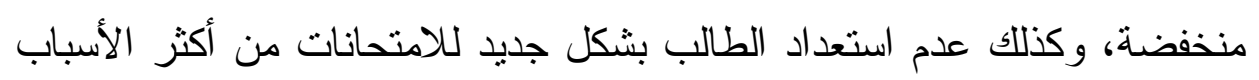

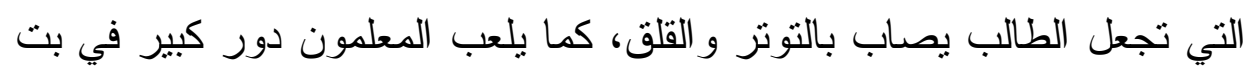

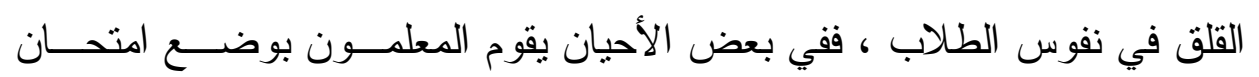

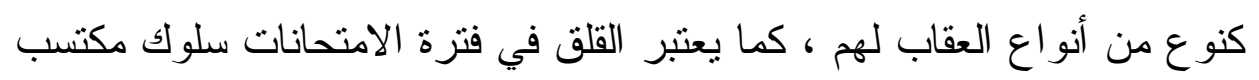

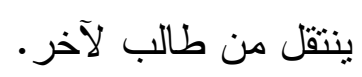

\section{أعر اض ومظاهر قلق الامتحان :}

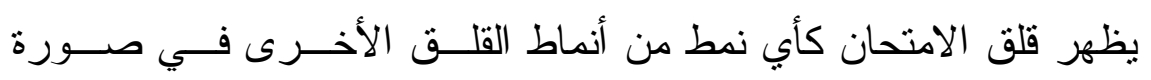

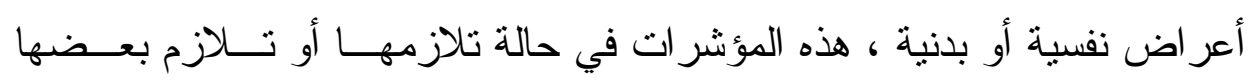

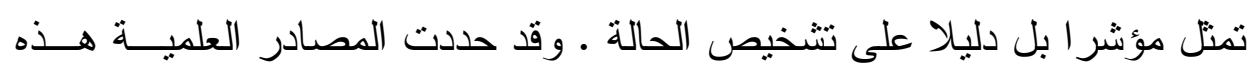

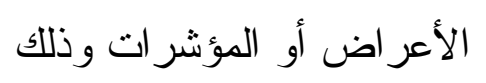

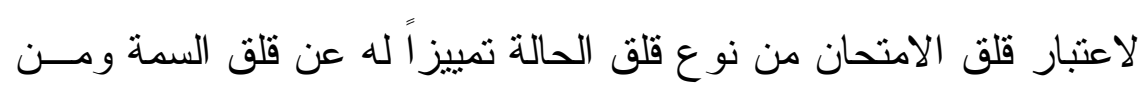

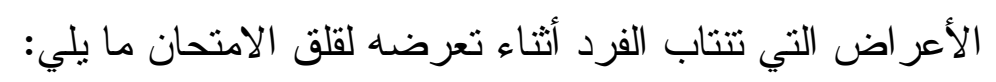

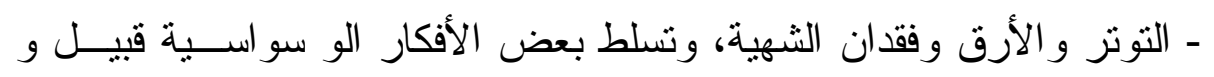

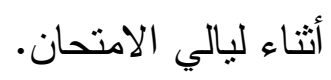

ـ كثرة التفكير في الامتحانات و الانشغال قبل و أثناء الامتحان فـي النتــائج

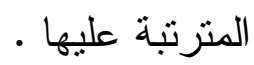




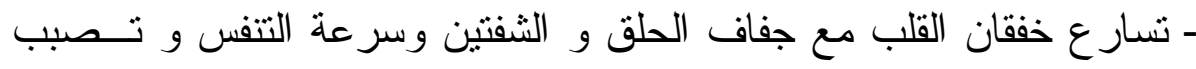
العرق، و ألم البطن و الغثيان. - الثعور بالضيق النفسي الثديد قبل و أثناء تأدية الامتحان.

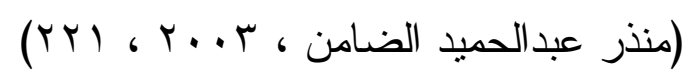

$$
\text { - اضطوف و الرهبة من الامتحان و التونز قبل الامتحان. }
$$
- الارتبالك و التوترونقص الاستقرار و الأرق ونقص النقة بالنفس. - تشتت الانتباه وضعف القدرة على التركيز واستدعاء المعلومات أثثـــاء أداء

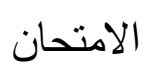

- الرعب الانفعالي الذي يشعر فيه الطالب بأن عقله صفحة بيضاءو و أنه نسى ما ذاكر بمجرد الإطلاع على ورقة أسئلة الامتحان.

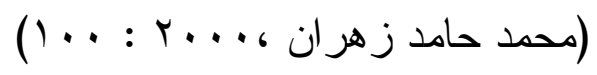

وترى الباحثة أن هذه الأعر اض و السلوكيات الفـسيولوجية و الانفعاليــة

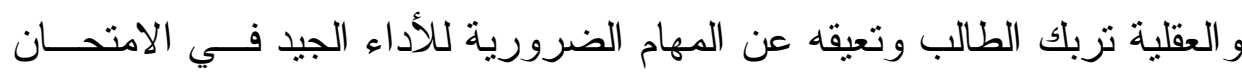

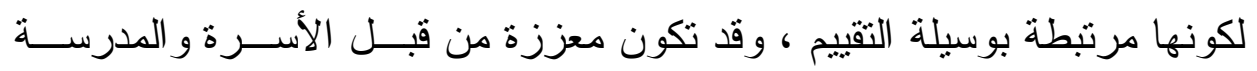

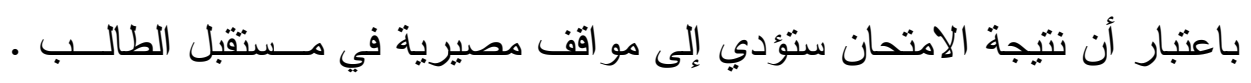

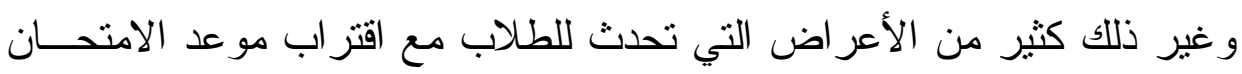

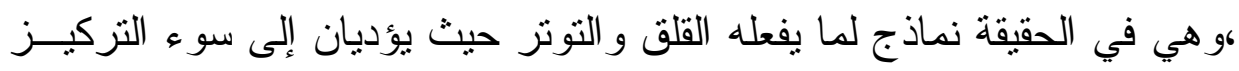

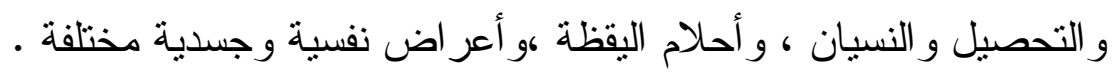




\section{قلق الامتحان و التحصيل الدراسي :-}

يعد قلق الامتحان في صورته البسيطة بمثابة الدافع للانجاز و التحصيل ،

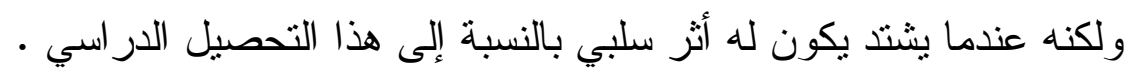

ويرى "سوليفان" Sollivan(به (190)، "أن القلق في أي سن يعـد عـاملا

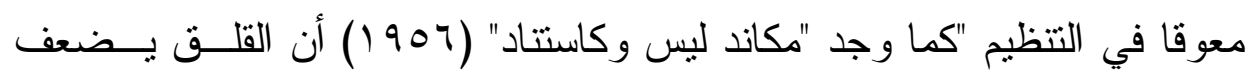

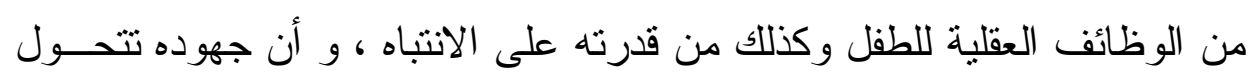

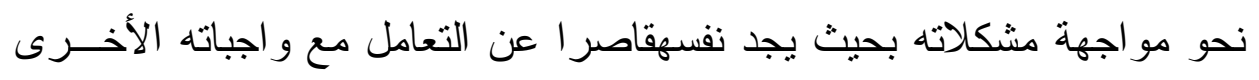
بنجاح.

كما بينت در اسات أخرى وجود ارتباطات ســالبة بـين القلـق و الـــكاء

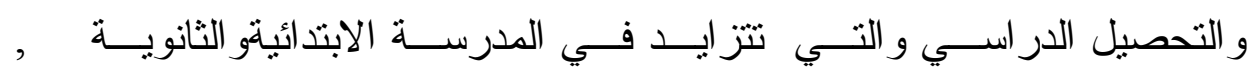
Sarason\&Zimbardo

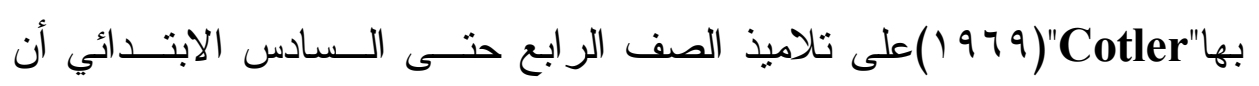

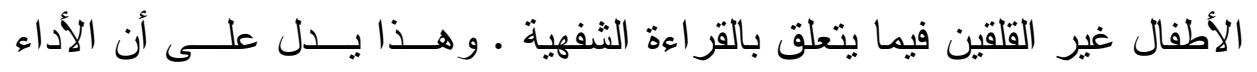

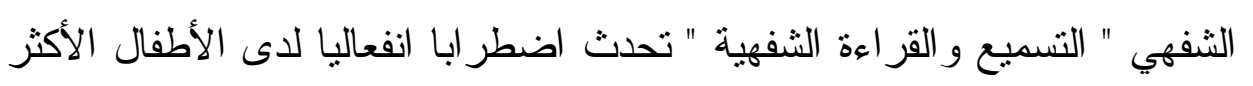
قلقا بسبب الضغط الناتج عن ذللك وقد دلت الدراسات أيضا أنه يوجد ارتباط موجب بين الدرجات العالية في

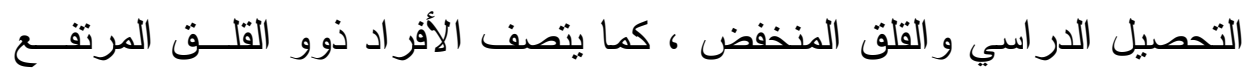

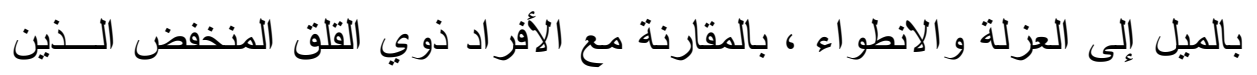

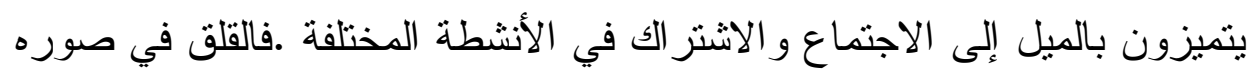

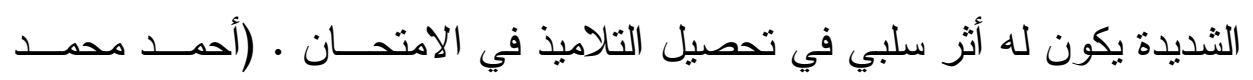

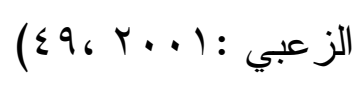




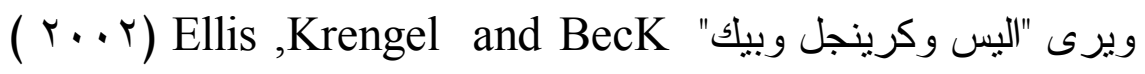

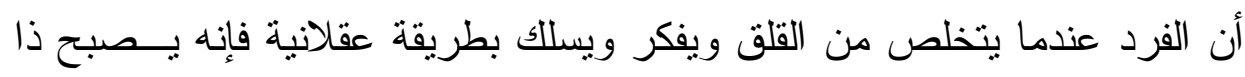

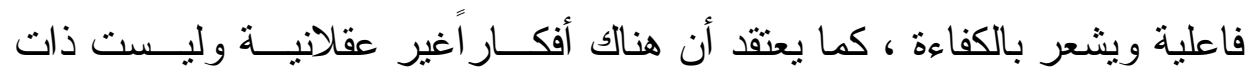

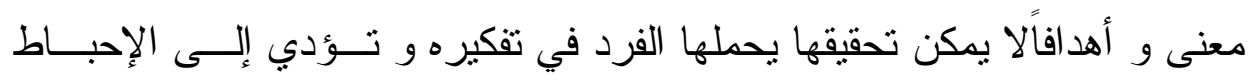
و الخوف الدائم

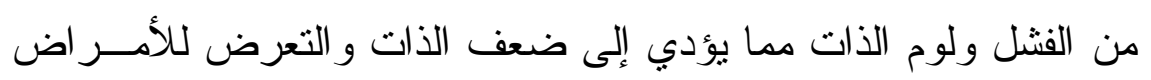

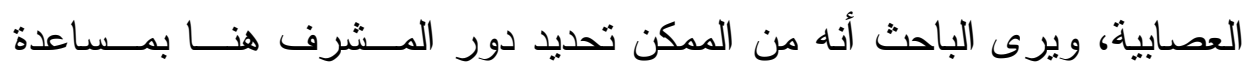

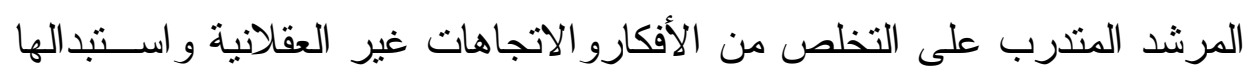

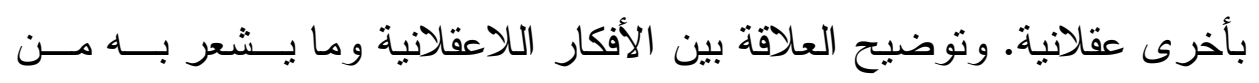
إحباط وعدم كفاءة ، إضافة أن على المشرف أن يوضح للمرشد المثند المندرب الآثار

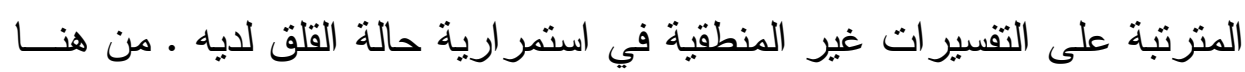

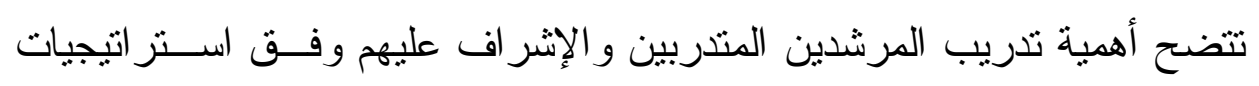

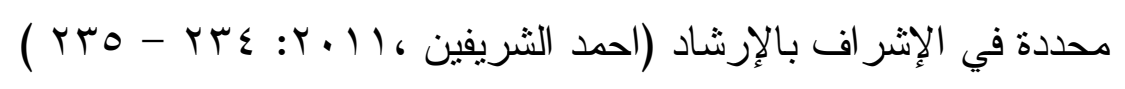

مما تقدم نستتنج أن القلق ظاهرة منتشرة بين الأفراد في هــذا العـصر

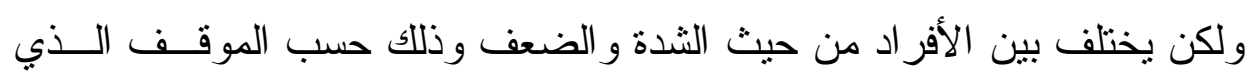

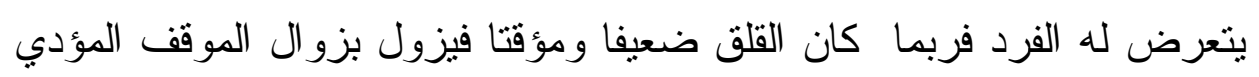

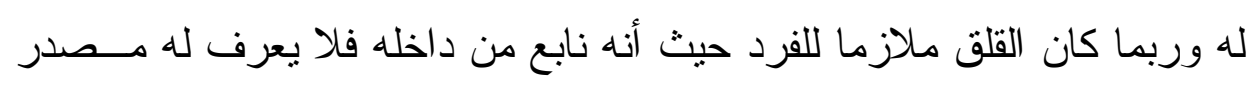

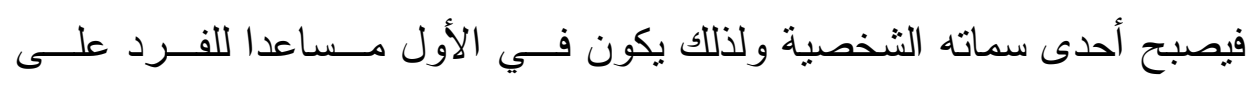

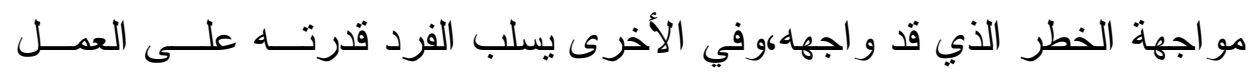
و التقدم و النجاح في حياته العامة.

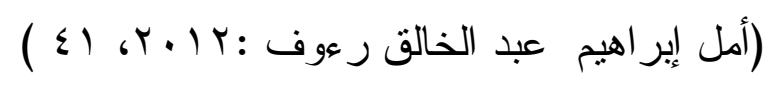


وترى الباحثة أن الطلاب يو اجهون في جميع مر احل التعلـيم مـشكلات

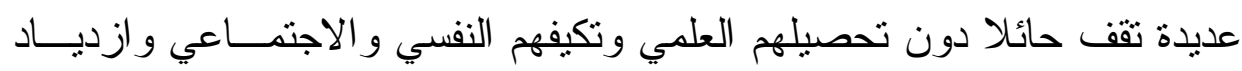

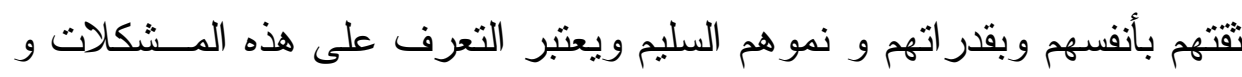

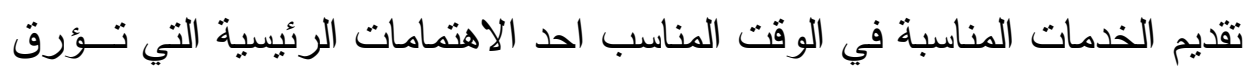

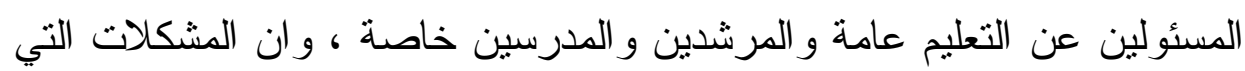

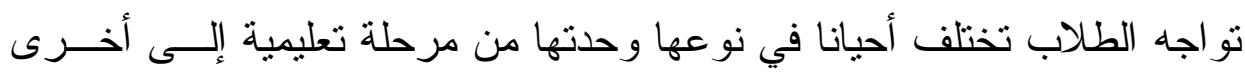

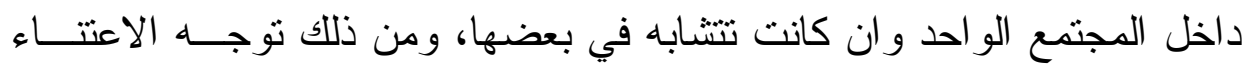

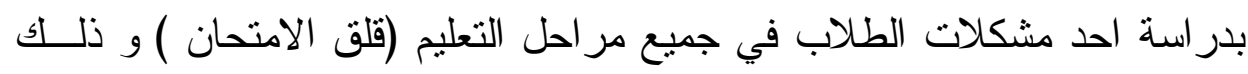

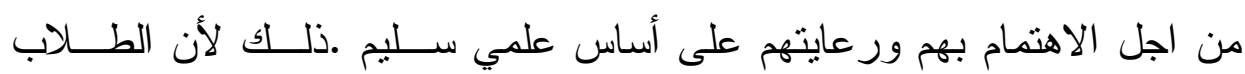

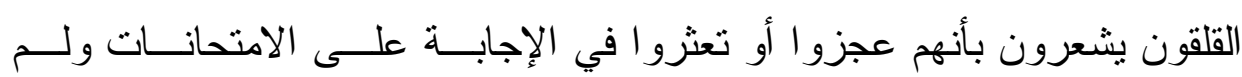

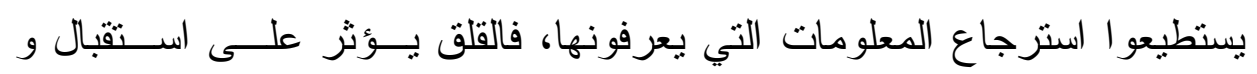

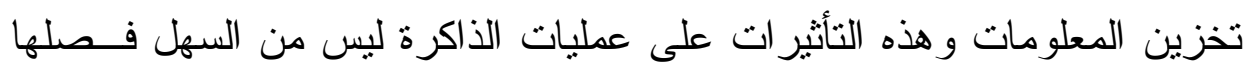
عن بعضها ، فالقلق الثديد يترتب عليه آثار عكسية تتمثل في اضطر اب الثات الأداء

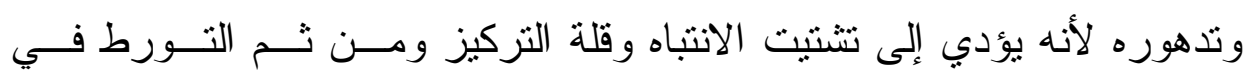

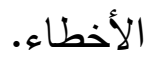

\section{نظريات قثق الامتحان :}

لقد حاولت كثير من النظريات الحديثة تقسير الإنجـــاز الــسئ الــــنبط

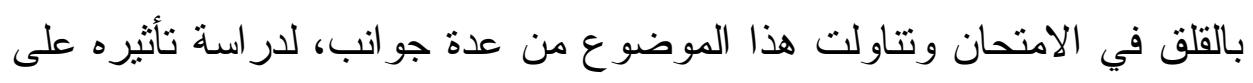

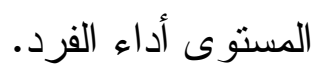




\section{1 - تفسير قلق الامتحان من وجهة نظر النظرية المعرفية:}

لقد حاولت كثثر من النظريات الحديثة تفسير الإنجــاز الـسيئ الـــرتبط

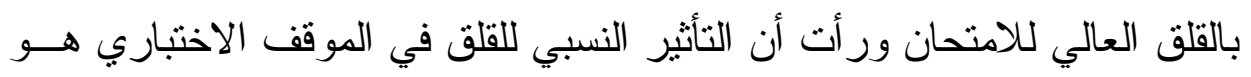

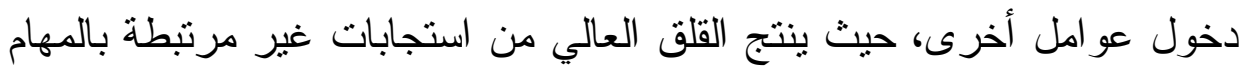

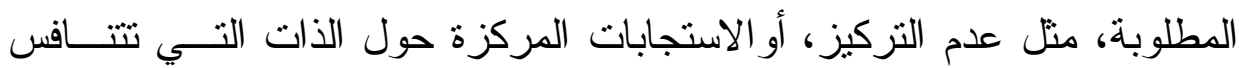

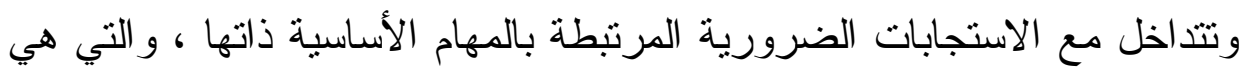

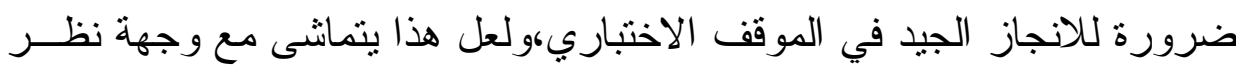

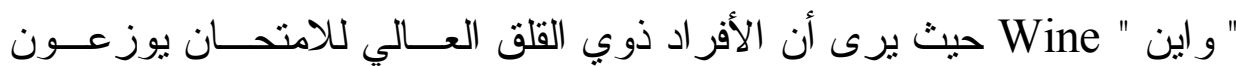

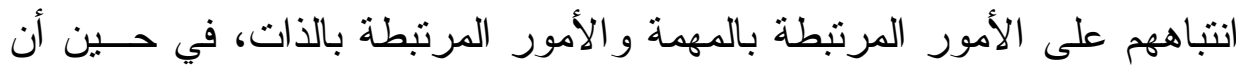

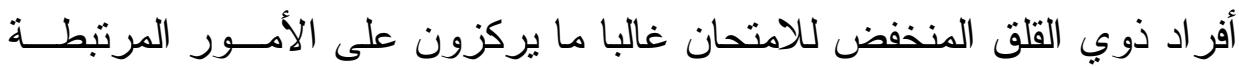
بالمهام المطلوبة فقط بدرجة أكبر •

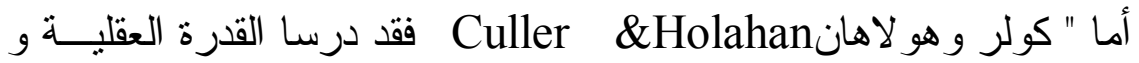
عادات الدراسة في الإنجاز الأكاديمي وقد وجد الباحثان أن لاى الطلبة أصحاب القلق العالي في الأتحان قدر ات منخفضة و عادات در اسية سيئة و على هذا فـإنان

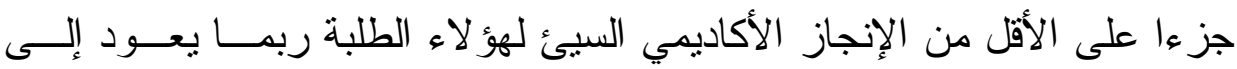

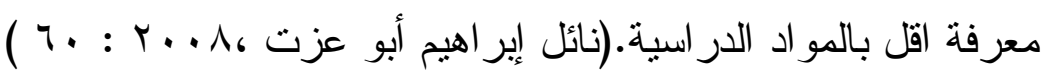
r - تفسير قلق الامتحان من وجهة نظر نظرية الجشطالت : رأت النظرية الجشطالتية أن القلق يعبر عن عــدم تطــابق بــين الـــات

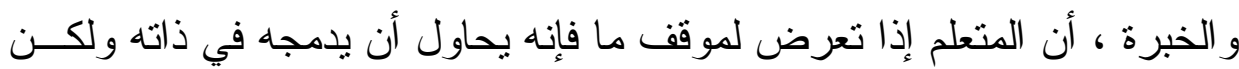

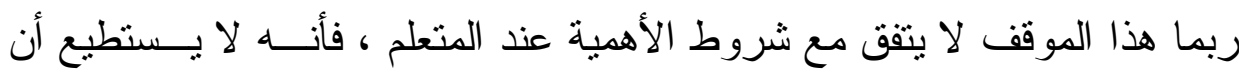


يرمزه بدقة في وعيه ويحاول تجنبها أو يرمزها بشكل مشوه ولذا ، فــإن حيــل

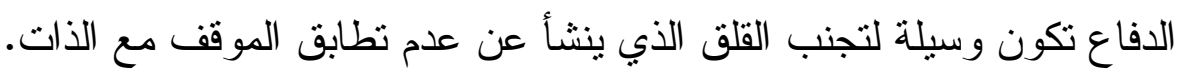

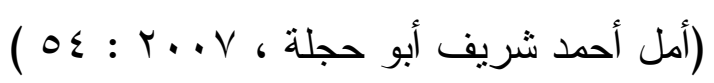

r- تفسير قلق الامتحان من وجهة نظر نظرية القلق الدافع: تفسر هذه النظرية قلق الامتحان على أساس أن الدو افع المرتبطة بموقف

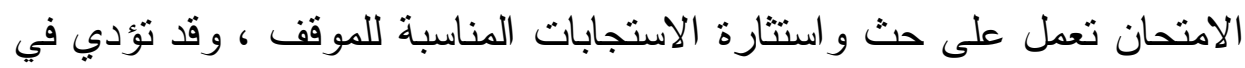

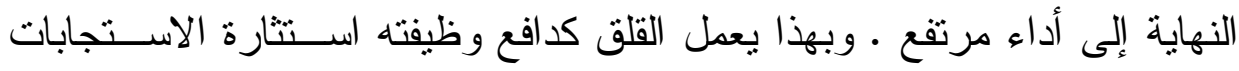

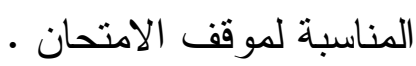

Taylor \& Spence" ويدعم هذا النموذج وجهة نظر" تـايلور وســبنس التي تقوم على أساس أن للقق خاصية الدافع الذي يوجه السلوك ، و ويدفع الفرد

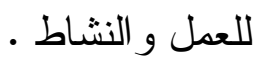
و أكد "تايلور وسبنس" Taylor \& Spence " في نظريتهما " القلق الدافع " أن شعور التلميذ بالقلق في الامتحان صفة حسنة تدفعه إلى تحسـين أدائسهـه ،

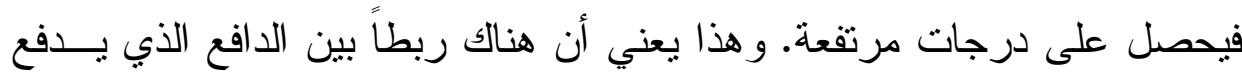

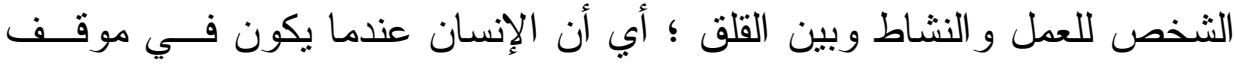

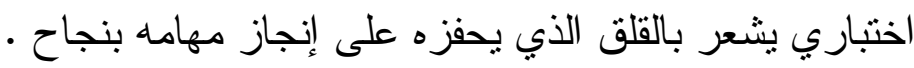
وقد أجريت در اسات كثيرة على علاقة القلق بالتحــصيل الدراســي فــي

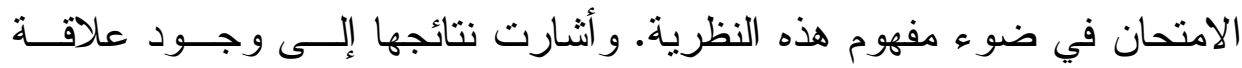

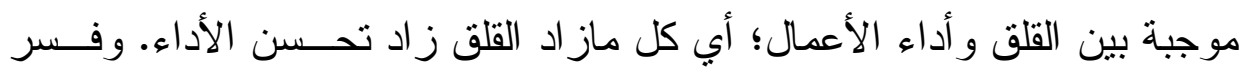

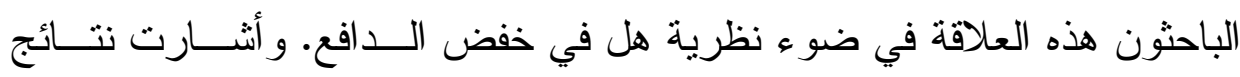


أخرى إلى وجود علاقة منحنية بين القلق و التحصيل في الامتحان؛ أب كل ماز اد

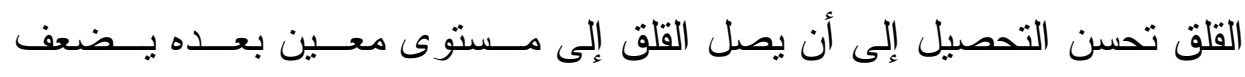

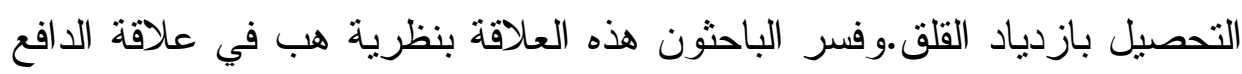

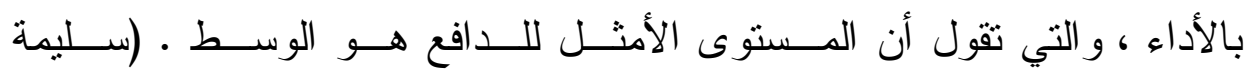

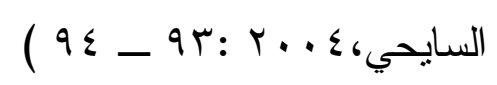

ع - تفسير قلق الامتحان من وجهة نظر معالجة المعلومات

قدم بنجمين وزملائه نموذج معالجة المعلومات و الذي يزودنـــا بمفــاهيم

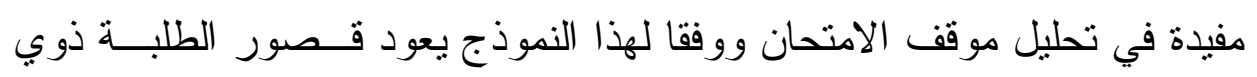

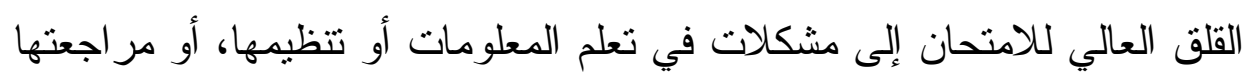

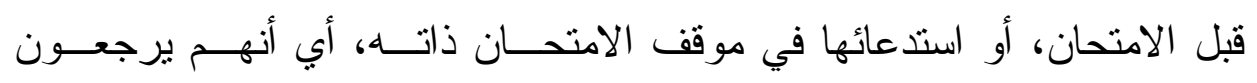

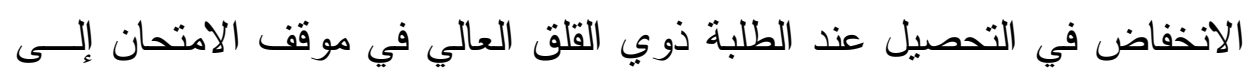

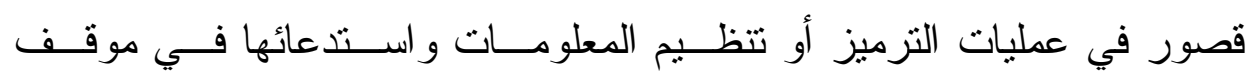
الامتحان.

ه- تفسير قلق الامتحان من وجهة النظر النظرية السلوكية

يرى السلوكيون أن الأفر اد بيتخدمون استر اتيجيات تكيفية منها ايجابيــة

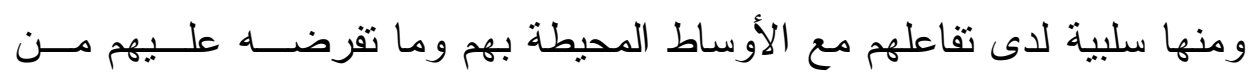

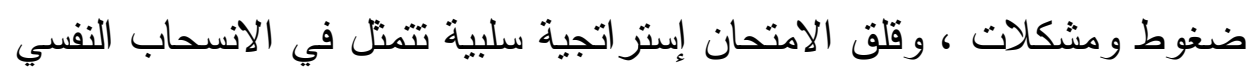

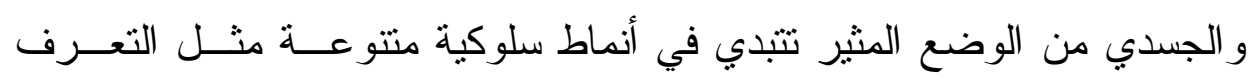
وزيادة إفراز الأدرنالين و البكاء و عدم القدرة على مسك القلم و الكتابة و التشنج.

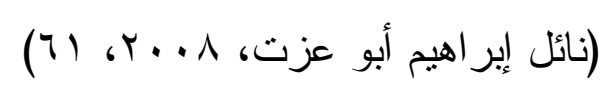


الإجراءات العملية التعليمية الإرشادية لقلق الامتحان :

يقتر ح بعض الأخصائيين النفسيين أن هناك بعض الإجـــراءات العمليـــة

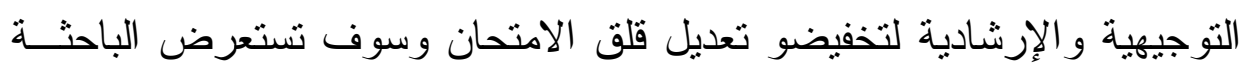
أهم هذه الإجر اءات و هي كالتالي :

التدريب على مهارات الاختبار منها :

1 - مهارة تحديد الأهداف من المذاكرة :

يرى لويس لاس Lasse (1996) أن " من الضروري أن يكون الطالــب

قادر ا على أن يحدد أهدافه الثخصية ، و أهداف الدر اسة و الدذاكرة ، و أن يخطط

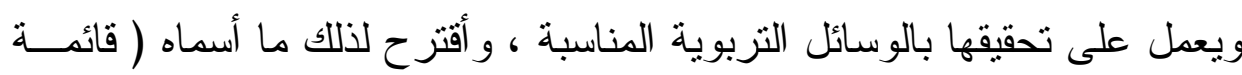

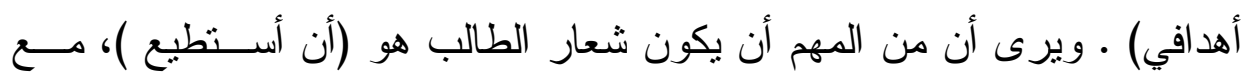

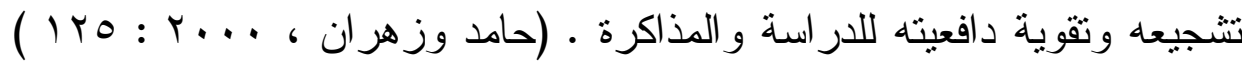

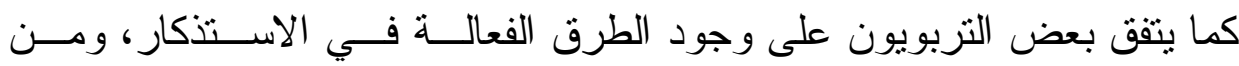

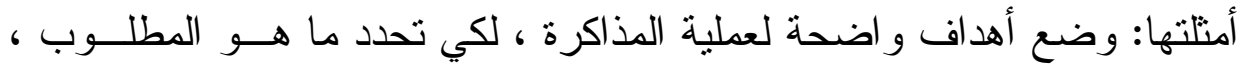

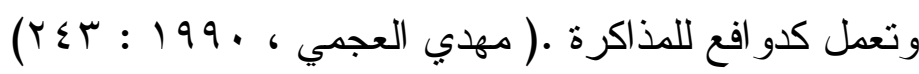

r - مهارة تخطيط المذاكرة :

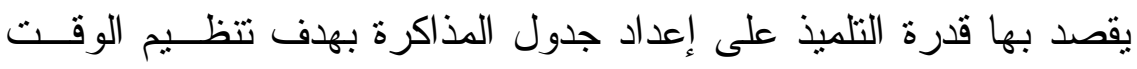

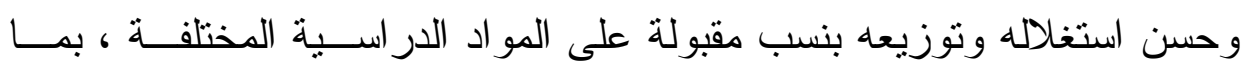

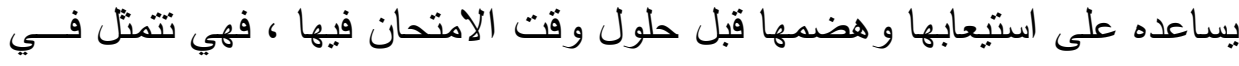

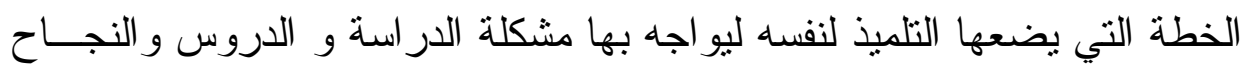

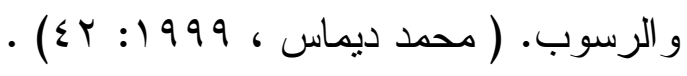




\section{وهذه الخطة توضع على مرحلتين هما :}

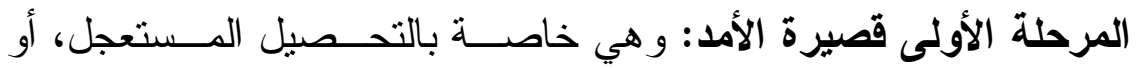

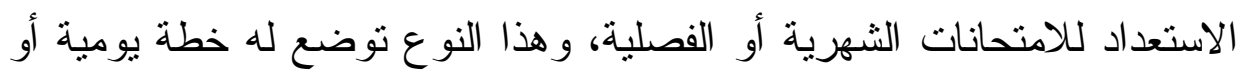

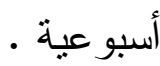

المرحلة الثانية طويلة الأمد : وهي خاصــة بكسب المعرفــة بـشكلها

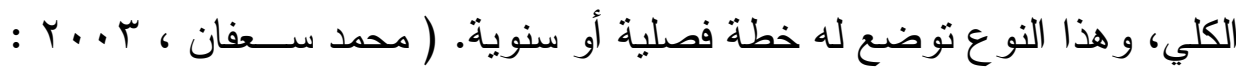

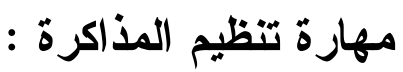

يقصد بها تتظيم الوقت، وتتظيم المكان. ومن المهم إتقان مهــارة تتظـــم

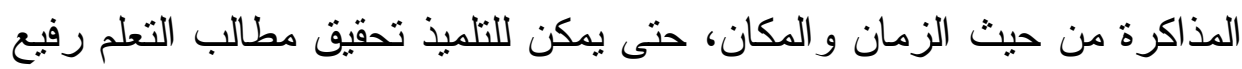
المستوى، وحتى يتحقق أعلى مردود وظيفي لعملية الدراسة.

ويتطلب تتظيم الوقت تتظيم الأعمال، و أداء الو اجبــات المنزليــة،وتتظيم

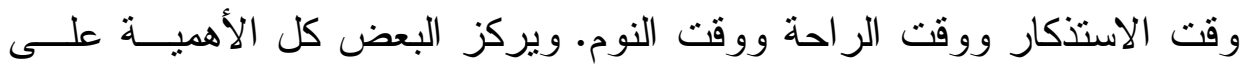

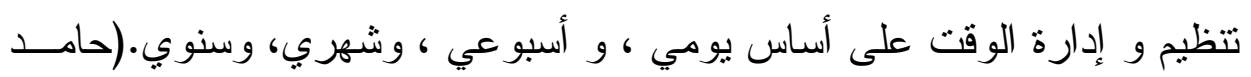

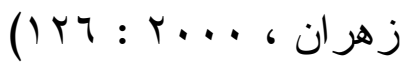

ويجب الاهتمام بتتظيم مكان الاستذكار ، بحيث يكون فيه مكتـب صــير

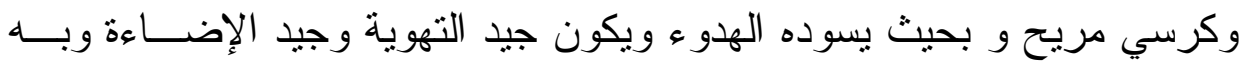

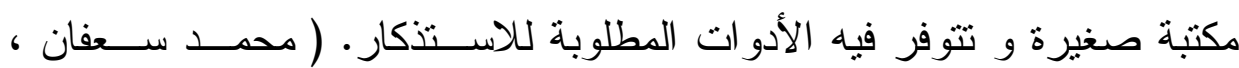




\section{ع - مهارة المراجعة:}

مهارة المر اجعة من أهم المهار ات التي ينبغي أن يكتسبها أي طالب يمـر

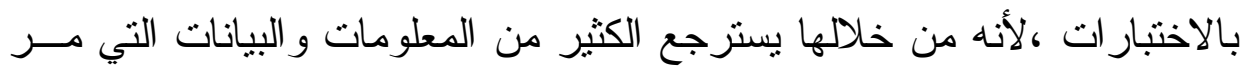

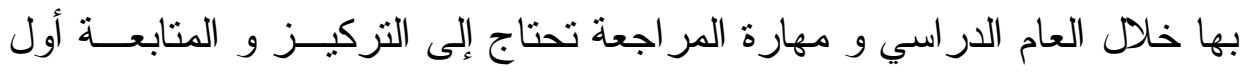

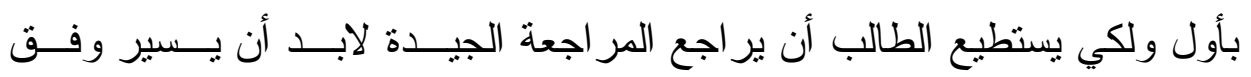

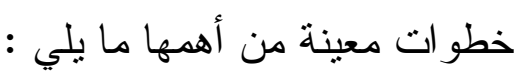
- تدوين أكثر النقاط أهمية في كراسة الملاحظات . - مر اجعة هذه الملاحظات دوريا و التلخيص قدر المسنطاع. - المر اجعة حسب الجدول الزمني المحدد.

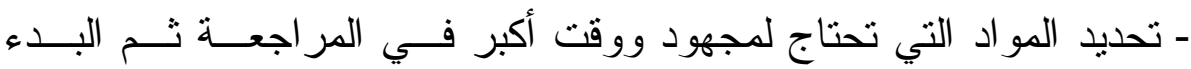
بدر استها أو لا.

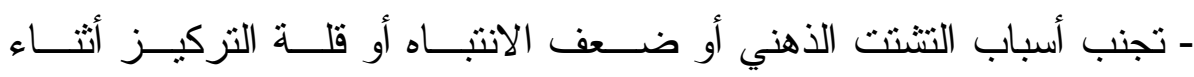
المر اجعة.

- المر اجعة المنظمة لجميع المو اد المقررة ووضع المادة الصعبة مع مادة أقل صعوبة. - استخدام الألو ان للتأثشير على النقاط المهمة.

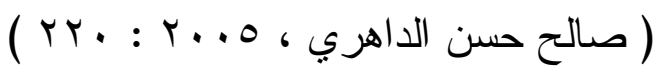




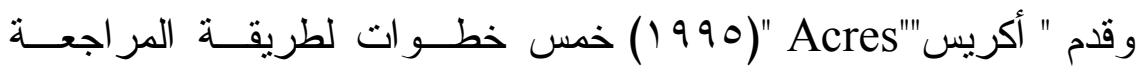

ـ قر اعة الملاحظات و البحث عن إجابات للأسئلة المفتوحة .

- تذكر ما يقرا ، أو الثعور بالفهم للملاحظات السابقة .

- تحديد هل الموضوع المر اد مر اجعته أصبح و اضحا ومفهوما،أم يحتاج إلى إلى

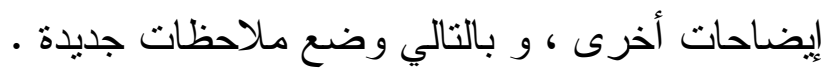

- مر اجعة الملاحظات الأصلية مع الملاحظات الجديدة حتى يتم تــكر كـلـ الإجابات عن الأسئلة التي وضعت في الخطوة الأولى.

- إعادة قراءة الملاحظات كما في الخطوة الأولى، ومحاولة النظر الدقيق في

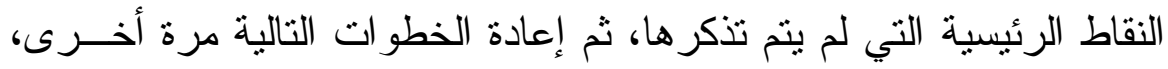

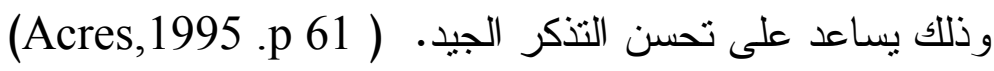

\section{0 - مهارة الاستعداد للاختبار :}

الاستعداد للاختبار من الأمور الهامة و إن كان الطالب متقدم إلى اختبـار

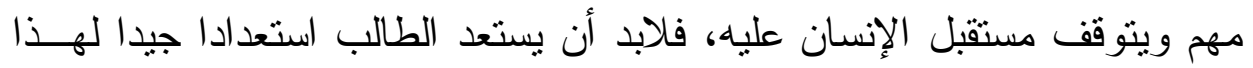
ومن أهم خطو ات الاستعداد للاختبار ما يلي:

- عدم السهر طويلا لأن السهر يرهق الجسم ويتعبه ويخرج الإنسـسان عـن

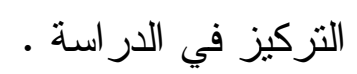

ـ الابتعاد عن شرب المنبهات لأنها تأخذ مــن قــدرة الطالـبـ وتركيـزهو و

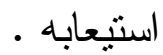


- المحافظة على وجود حالة من التهيؤ النفسي الطيب للتعامل الجيد الفعال مع

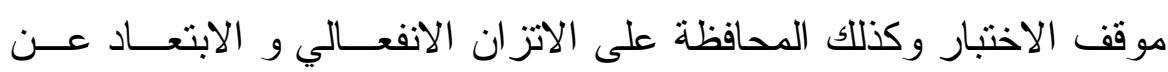
النوتز و القلق •

$$
\text { צ- - 2 - مهارة أداء الاختبار }
$$

- الجلوس في المكان المخصص بهدوء وكتابة البيانات الثخــصية، وإتبـــاع التعليمات التي تلقى على الطالب من لجنة سير الأتحان. - الكتابة بخط و اضح، وتتظيم كر اسة الإجابة. - عدم محاولة الغش و المحافظة على الهدوء النفسي التام أثناء الامتحان . ــ الامتحان يحتاج نو عا من الاجتهاد و الحكمة في التعامل مع ورقـــة الأســـلة من حيث جسن قر اعتها، وحسن اختيار الأسئلة وحسن الإجابة.

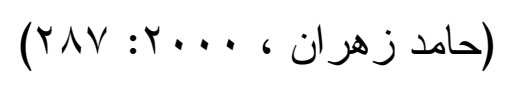

كما يتم الاستعداد للامتحان على المدى البعيد ، حيث يحدد التلميذ أهدافــهـ

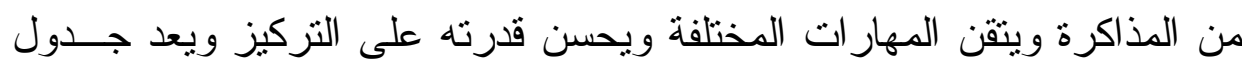

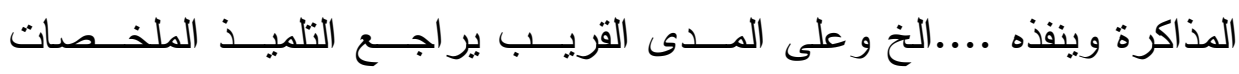

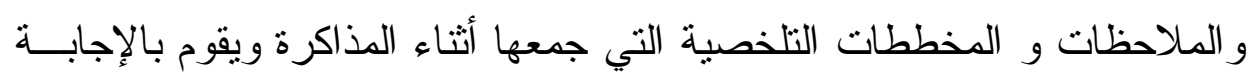

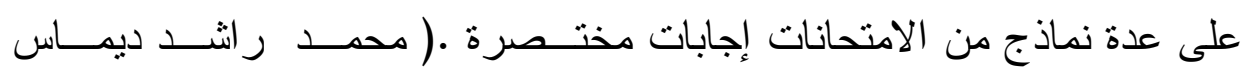
() $\leqslant 0: 1999$ ، ترى الباحثة أن قلق الامتحان يكون مفيدا للتناميذ وطريقا سهلا للنجاح و

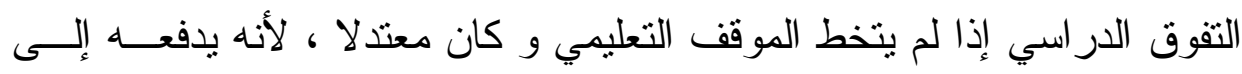

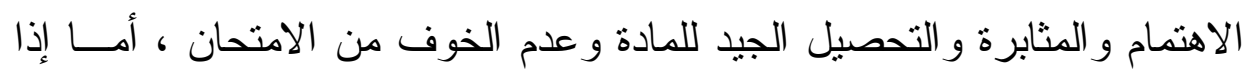


تخطى القلق الموقف التعليمي و أصبح تأثثيره قويا فإن الأداء يتدهور مما يــؤدي

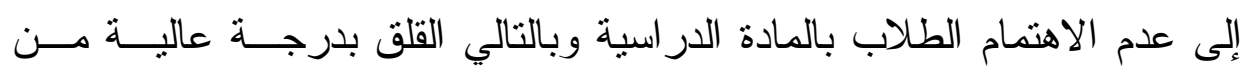

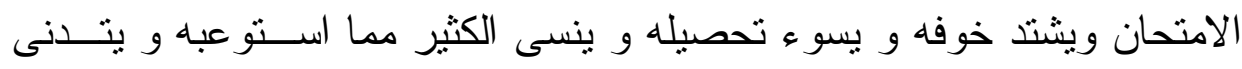

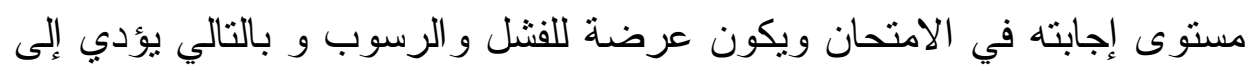

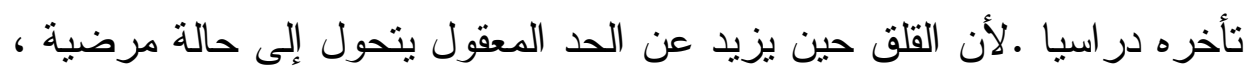

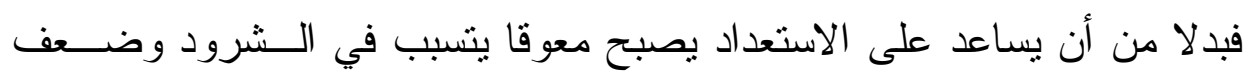

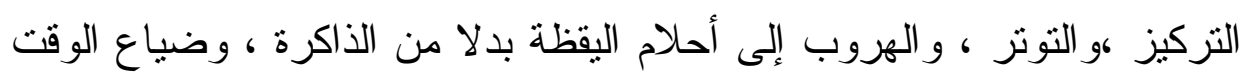

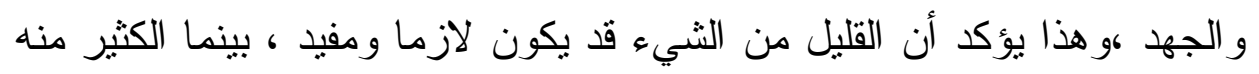

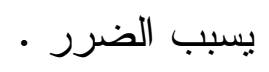

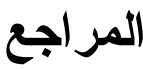

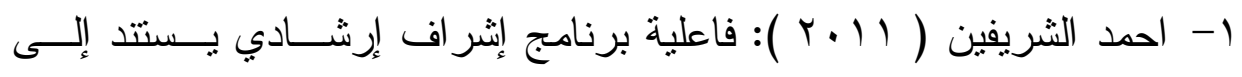

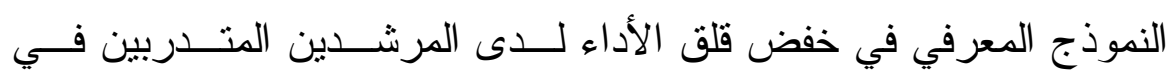
الأردن، المجلة الأردنية في العلوم التربوية ، مجلد(V) ) ، العدد (r ) ).

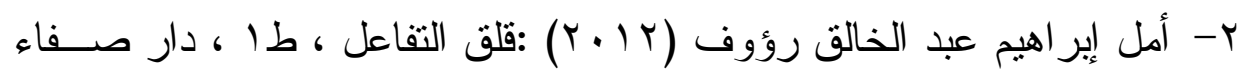

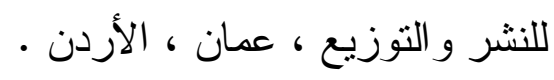

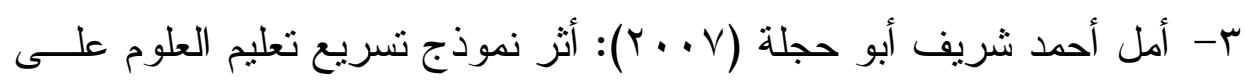

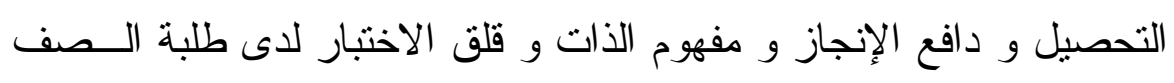

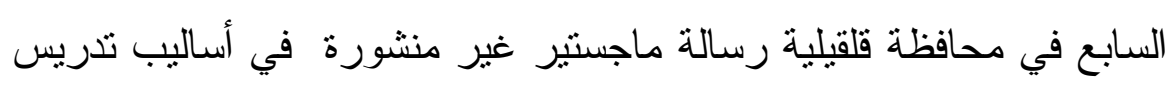

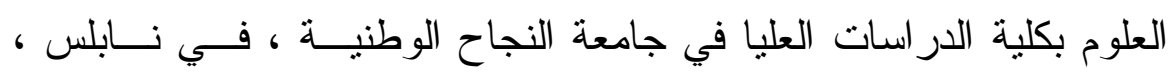
فلسطين 
ع- سامر جميل رضوان (ץ . . r) : الــصحة النفـسية ،ط ا، دار الــسيرة ،

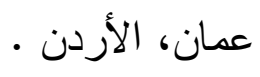

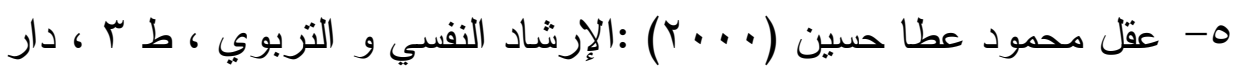

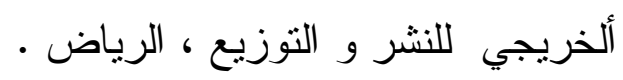

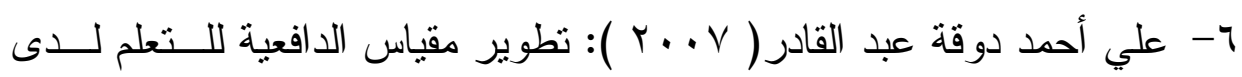

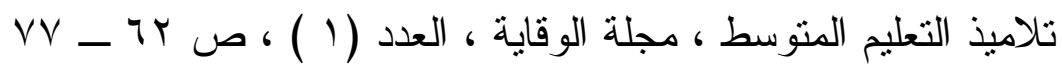

V- فرج عبد القادر طه ، وآخرون : مصطفى كامل عبد الفتاح ، حسين عبــ

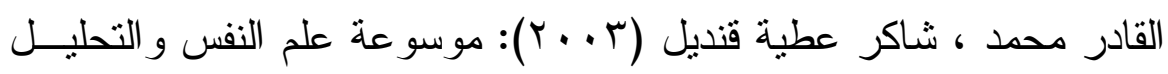

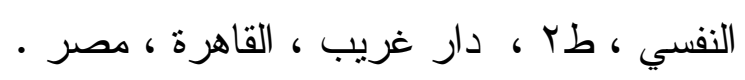

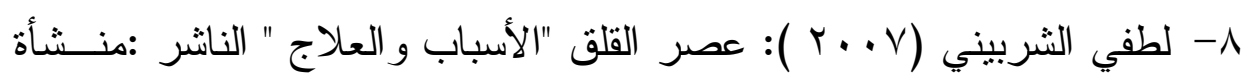

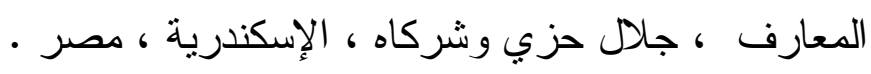

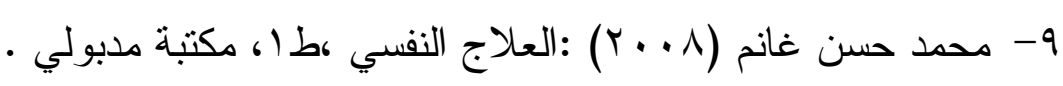
• 1- محمد راثند ديماس (999 199) : أسرار التفوق الدراسي ، طا ، دار إبــن

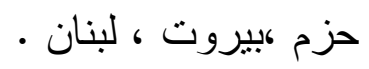

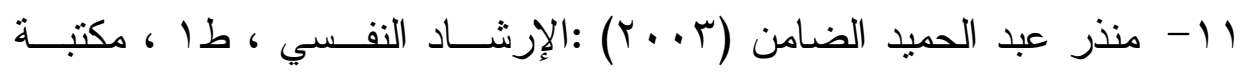

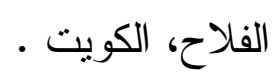

rا - مهدي مهدي العجمي (•99 1) : عادات وطرق المذاكرة التي يتبعها طلبة

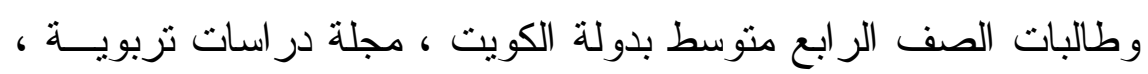

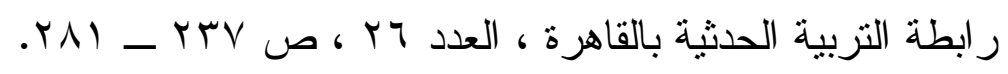




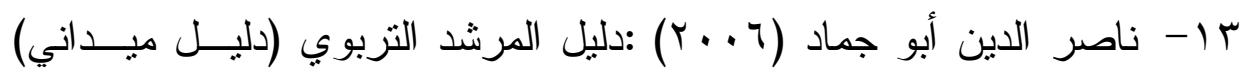

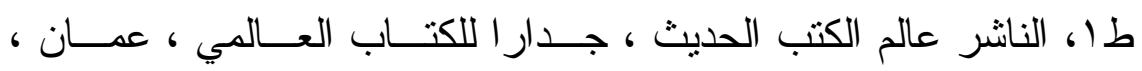

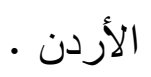

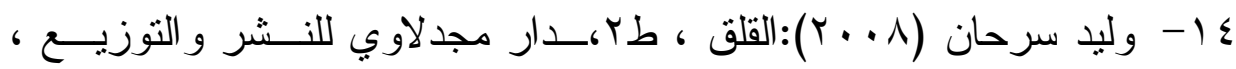

عمان ، الأردن. 